\section{Researchers still at odds}

\section{Washington \& Boston}

Although the greenhouse effect can be blamed for making environmentalists out of many of the world's leaders, including both US President George Bush and French President François Mitterrand, many researchers are still not convinced that there is a link between gases accumulating in the atmosphere and observed global warming.

Disagreement about current climate models was apparent last week at a Harvard University seminar on "Understanding global warming". James Hansen, chief of the NASA Goddard Institute for Space Studies claimed a "high degree of confidence" in the cause and effect relationship between the greenhouse effect and observed climate change. But Thomas Karl of the National Climatic Data Center has a "small degree of confidence in the link". And Ron Prinn, professor of meteorology at Massachusetts Institue of Technology, takes the middle way, describing the link as a "quite plausible hypothesis".

The uncertainties in the models are large, says Karl, and so are the temperature data collected over the past century. $\mathrm{He}$ pointed out that the time of day at which temperatures are taken has sometimes changed, as have the kinds of shelters in which thermometers are housed. And monitoring stations have moved from city centres to suburban airposts.

A report* issued last week by the George C. Marshall Institute, a Washington-based think tank, adds to the doubts. It says that solar variability might provide a better explanation for the 100 -year rise in mean temperature than increased concentrations of carbon dioxide. If that is correct, then only a small greenhouse effect might be expected in the next century.

The report's authors are Frederick Seitz, Robert Jastrow and William Nierenberg - former heads of the National Academy of Sciences, the NASA Goddard Institute for Space Studies and the Scripps Institution of Oceanography. Before policy-makers begin corrective programmes, the authors argue that the uncertainties of greenhouse forecasts must be reduced.

They advocate a $\$ 100$-million investment in advanced supercomputing facilities to do the job. Bigger computers would allow a better treatment of the role of oceans and clouds in modulating the greenhouse effect and provide fine-scale predictions of regional changes in climate.

Seth Shulman \& Alun Anderson

*Scientific perspectives on the Greenhouse Problem, George C. Marshall Institute, Washington DC.

\section{Washington}

ENVIRONMENTALISM is all the rage in the United States, and even long-time opponents of the conservation movement are finding it pays to change views. In Washington, power-company executives are seen holding press conferences with energy-conservation lobbyists, Congressman from the industrial mid-Western states queue up to support greenhouse-gas legislation and President George Bush is praising the environmentalists who for the past eight years were not permitted past the White House gates.

Bush's kind words for the environmentalist movement came last week as he announced proposals to "curb acid rain and cut urban smog and clean up air toxics" through a new clean air act. But the kind of environmentalism that is finding favour with Bush and his friends in industry has a new slant, substituting the power of market forces for moral outrage and blanket control measures.

The new approach has been heard of before, but did not emerge as a comprehensive philosophy until the publication of "Project 88, Harnessing Market Forces to Protect our Environment", a report drafted by Robert Stavins, professor at the Kennedy School of Government at Harvard University. Last week, an impressive array of representatives of the president, the Environmental Protection Agency, conservation groups, congressmen and academics turned out to endorse its approach.

Project 88 's ideas have already had an impact on Bush's clean air act proposals. Bush wants "to end acid rain by the end of the century" by cutting sulphur dioxide emissions by almost half, along with cuts in nitrogen oxide. Federal regulators' first impulse on hearing that sort of news is to rush for a new set of tough emission standards for all power plants. But Bush intends to follow Project 88 and set only total output limits and then leave private industry to decide how to meet them by trading pollution credits among themselves. An electric power company may decide to earn credits by switching to low-sulphur coal or installing expensive scrubbers. Or it may find it less expensive to buy pollution credits from other plants that can cut pollution more easily.

The result should be that industry as a whole is under constant pressure to find the cheapest and easiest way to cut total pollution levels. New plants will probably meet high standards easily, gaining credits, while old plants is more likely to be covered by buying pollution credits rather than by expensive alterations. Under the old "command and control" system every plant would have to meet the same standard, regardless of cost. The idea has already been tried out in a limited way and, according to EPA figures, is saving $\$ 500,000$ a year. The EPA says that full implementation will save $\$ 3,000$ million a year by 1995 over uniform emission standards designed to produce the same effect.

The Canadian government, which sees much of the US sulphur dioxide emissions end as acid rain on its territory, is pleased with the proposed reductions and also interested in the concept of making market forces drive pollution reduction. If the people rushing to endorse Project 88 are right, the idea has wide application. Project 88 lists 36 possible new policies; among them is a deposit-refund scheme, just like that used to encourage people to recycle bottles, that could end toxic dumping. The idea is for toxic chemicals to be sold with a deposit that would be returned when the waste was turned in at a facility for recycling or disposal.

The new trend to make conservation just another place to do business worries some environmentalists who see it as slippery slope that bypasses moral sanctions and leads to weaker policies. But it is already proving a success in New England where two long-time adversaries, the Conservation Law Foundation and Northeast Utilities, a large electric power company, decided last year to end five years of litigation and start collaborating. The result is a scheme in which a group of power companies are paying their customers to use less electricity by giving them energy-efficient equipment. Although power-company accountants may not at first be happy with the idea that reducing demand is good for profits, when conservation means that the utility need not spend millions on a new plant, the idea looks very attractive. Essentially, the power company makes money by buying efficency improvements that save power at less the total cost of generating it.

If such big savings can be made, why do people not buy energy-efficient equipment without help from power companies? The answer is that savings are made over a long period, and people do not have the long-term perspective of power companies. The scheme was assessed at a World Resources Institute meeting earlier in the month by Doug Foy, President of the Conservation Law Foundation and William Ellis, president of Northeast Utilities. Ellis charted his road to support for energy conservation as having passed through "disbelief and denial, then skepticism and grudging acceptance". The two said that New England power companies will spend $\$ 100$ million on energy-efficiency programmes this year. By 1995 they will spend $\$ 500$ million a year.

Alun Anderson 